\title{
Technology indicators: population, labour and schooling : 1992 report
}

Citation for published version (APA):

van Dam, J. W., \& Ramaekers, G. W. M. (1992). Technology indicators: population, labour and schooling: 1992 report. Researchcentrum voor Onderwijs en Arbeidsmarkt, Faculteit der Economische Wetenschappen. ROA Reports No. 5E https://doi.org/10.26481/umarep.199205E

Document status and date:

Published: 01/01/1992

DOI:

10.26481/umarep.199205E

Document Version:

Publisher's PDF, also known as Version of record

\section{Please check the document version of this publication:}

- A submitted manuscript is the version of the article upon submission and before peer-review. There can be important differences between the submitted version and the official published version of record.

People interested in the research are advised to contact the author for the final version of the publication, or visit the DOI to the publisher's website.

- The final author version and the galley proof are versions of the publication after peer review.

- The final published version features the final layout of the paper including the volume, issue and page numbers.

Link to publication

\footnotetext{
General rights rights.

- You may freely distribute the URL identifying the publication in the public portal. please follow below link for the End User Agreement:

www.umlib.nl/taverne-license

Take down policy

If you believe that this document breaches copyright please contact us at:

repository@maastrichtuniversity.nl

providing details and we will investigate your claim.
}

Copyright and moral rights for the publications made accessible in the public portal are retained by the authors and/or other copyright owners and it is a condition of accessing publications that users recognise and abide by the legal requirements associated with these

- Users may download and print one copy of any publication from the public portal for the purpose of private study or research.

- You may not further distribute the material or use it for any profit-making activity or commercial gain

If the publication is distributed under the terms of Article $25 \mathrm{fa}$ of the Dutch Copyright Act, indicated by the "Taverne" license above, 
TECHNOLOGY INDICATORS: POPULATION, LABOUR AND SCHOOLING

- 1992 Report -

ROA-R-1992/5E

J.W. van Dam

G.W.M. Ramaekers

RESEARCH CENTRE FOR EDUCATION AND THE LABOUR MARKET

Faculty of Economics and Business Administration

Rijksuniversiteit Limburg

Maastricht, December 1992 


\section{CIP-GEGEVENS KONINKLIJKE BIBLIOTHEEK, DEN HAAG}

Dam, J.W. van

Technology indicators: population, labour and schooling : 1992 report / J.W. van Dam, G.W.M. Ramaekers. - Maastricht : Research Centre for Education and the Labour Market, Faculty of Economics and Business Administration, Rijksuniversiteit Limburg. - (Report / Research Centre for Education and the Labour Market, ISSN 0922-8098; 1992/5E)

Met lit. opg.

ISBN 90-5321-097-0

Trefw.: onderwijs en arbeidsmarkt; Nederland 


\section{CONTENTS}

\section{TABLES}

\section{ACKNOWLEDGEMENT}

1. INTRODUCTION

2. KEY INDICATORS 2

2.1. Introduction 2

2.2. Initial education 3

2.2.1. Dual education 3

2.2.2. Share of vocational education in total regular education 4

2.3. Labour force and school-leavers 5

2.3.1. Share of technically skilled persons in the total number of 5 school-leavers and in the labour force

2.4. The need for training 6

2.4.1. Labour market situation for the technically educated: tension indicators 6

$\begin{array}{ll}\text { 2.4.2. Age composition of the (active) population } & 7\end{array}$

2.5. Educational efforts $\quad 10$

2.5.1. Proportion of the potential labour force in post-elementary education $\quad 10$

2.5.2. Proportion of apprenticeship labour in the labour volume of industrial sectors

3. INCIDENTAL SURVEYS 14

3.1. R\&D workers $\quad 14$

3.2. Vacancies 14

3.3. Migration 16

$\begin{array}{ll}\text { 3.4. Self-employment } & 17\end{array}$

3.5. Expenditure on labour market programmes 18

4. RESPONSE FROM THE NETWORK AND INTEGRATION OF DATA COLLECTION 21

4.1. Mailing and response from the network of associated institutes 21

4.2. Integration of data collection in Europe $\quad 21$

4.2.1. Initiatives included in last year's report $\quad 21$

4.2.2. Recent initiatives 22

5. CONCLUSIONS 24

ABBREVIATIONS 26

$\begin{array}{ll}\text { SOURCES } & 27\end{array}$

APPENDIX I : CLASSIFICATION OF INDUSTRIAL SECTORS 29

APPENDIX II: INFORMATION RECEIVED FROM THE NETWORK 


\section{TABLES}

Key indicators:

Table 1 : Proportion of dual-system students in total population between the ages of 15 and 24; 1983-90

Table 2 : Indicator of the share of vocational education (second and third levels); 1975, 1980-89

Table 3 : Share of technically trained (school-leavers and labour force); 1982/83-2008/09

Table 4 : Unemployment rates among school-leavers (May figures); 1986-91

Table 5 : Percentage shares of age groups in total population; $1980-90$

Table 6 : Percentage shares of age groups in active population; 1980-90

Table 7 : Participation in schooling (in the wide sense) as a percentage of the potential labour force between the ages of 15 and $49 ; 1983-90$

Table 8 : Participation in schooling (in the narrow sense) as a percentage of the potential labour force between the ages of 15 and $49 ; 1983-90$

Table 9 : Percentage of labour volume contributed by employees with primary apprenticeship agreements, by industrial sector; 1975, 1980, 1985-90

Table 10 : Percentage of labour volume contributed by employees with secondary apprenticeship agreements, by industrial sector; 1975, 1980, 1985-90

Research and Development:

Table 11 : Costs and quality of R\&D workers in companies; 1987, 1989

Vacancies and Migration:

Table 12 : Vacancy level, unemployment and vacancy duration; 1990

Table 13 : Reasons for hard to fill vacancies, according to industrial companies; 1985-86, 1989, 1991 (\% of companies agreeing)

Table 14 : Average rates of net migration (entries minus exits) per thousand population; 1983 $87,1988,1989$

Table 15 : Trend in the percentage share of foreigners or immigrants in the total labour force; 1980, 1989

\section{Self-employment:}

Table 16 : Percentage share of self-employment in the total labour force and in employment by major sectors; 1986 or 1987

Table 17 : Percentage share of self-employment in selected branches of economic activity; 1985,1986 or 1987

Expenditure on labour market programmes:

Table 18 : Public expenditure on labour market programmes as percentages of GDP; 1990

Table 19 : Public expenditure on labour market training as percentage of GDP; 1985, 1990 


\section{ACKNOWLEDGEMENT}

This study was commissioned by the Dutch Ministry of Economic Affairs, Directorate for General Technology Policy. It has been carried out by Drs J.W. van Dam and Drs G.W.M. Ramaekers (project leader), assisted by M. Reiners.

It was the fourth study carried out by the ROA in the framework of a databank for technology policy, 'METING'. The first was performed in 1989 by $\operatorname{Dr} A$. de Grip and Mrs Drs W.J. Nusselder, and described in the ROA report 'Technology Indicators referring to Education and Labour' (ROA-R-1989/4E). The second study was carried out in 1990 by Drs J.W. van Dam and Dr A. de Grip. It was described in the ROA report 'Technology Indicators: Population, Labour and Schooling' (ROA-R-1990/5E). The third study, performed in 1991 by Drs J.W. van Dam, Drs B.J.H. Lodder and Drs G.W.M. Ramaekers, was presented in the ROA report 'Technology Indicators: Population, Labour and Schooling' (ROA-R-1991/9E).

The report now lying before you is a follow-up to the previous ones. Chapter 2 describes the updating of six of the seven key indicators developed so far, followed by a brief interpretation. Chapter 3 presents the results of some relevant incidental surveys, carried out by third parties. In chapter 4 the annual inventory of internationally comparable figures on population, labour and training that might be relevant to technology policy is presented. The report starts with an introduction in chapter 1 and is rounded off by a summary of this year's findings and some evaluating remarks in chapter 4 . Unlike the previous studies this study is only published in an English version. 


\section{INTRODUCTION}

The relation between technological development on the one hand and education and labour on the other is one of mutual influence. For one thing, the training of the labour force is an important determinant of a country's Research \& Development capacity. The degree of skill of the labour force thus influences the innovative capacity of the society. On the other hand, technological progress has a tremendous impact not only on the growth of the national economy and the shifts in the economic structure, but also on the volume and composition of employment, the contents of work functions, the demand for certain skills, and hence the nature and level of the training required. In this respect, the degree of skill the labour force possesses is an important determinant of the diffusion potential of technological progress.

The Directorate for General Technology Policy of the Dutch Ministry of Economic Affairs has developed a databank of indicators on the international economic position of the Netherlands with regard to the implementation of technology, called 'METING' ('MEASUREMENT'). The organisation and objectives of the METING databank are outlined in the report 'METING 2, Indicatoren voor de technologische positiebepaling van Nederland' (Ministry of Economic Affairs, 1990). One category of indicators of the METING databank refers to the technological potential of the labour force as an indication of the breeding ground for technological development. In 1990 it was decided that ROA should focus on selected internationally comparable 'key indicators' of labour and training (see Van Dam and de Grip, 1990).

From this year on, the research institute MERIT is responsible for maintaining and further expanding the METING databank. This means that ROA's contribution to METING is from now on channelled through MERIT. ROA continues to update the present key indicators and keeps trying to broaden and improve the existing indicators on the basis of a periodic scanning of relevant initiatives from international organizations, in order to establish internationally comparable indicators for education and employment.

This year's study consists, like last year's study, of two parts. The first part concerns the updating of the key indicators of the societal breeding ground for technological innovations, mostly on the basis of international statistical data sources of ILO, UNESCO, Eurostat, and OECD. In the second part of the study the network of statistical offices, research institutes and/or researchers was approached with a request for new figures to complete the existing key indicators and to explore the possibility of developing new indicators of population, labour and training. This network consists of some 60 statistical offices, research institutes and/or researchers in the Netherlands, West Germany, France, the United Kingdom, Sweden and the United States. In this report West Germany refers to the former 'Bundesrepublik Deutschland' before the reunification in 1990. The second part of the study also includes the annual search for incidental surveys by third parties. 


\section{KEY INDICATORS}

\subsection{Introduction}

This year attention is in the first place focused on updating the 'key indicators' of the societal breeding ground for technological advance, developed so far:

- relative participation in dual education;

- the share of vocational education in total regular education;

- the share of technically skilled people in the total number of school-leavers and in the labour force;

- the labour-market situation for the technically skilled;

- the age composition of the (economically active) population;

- the proportion of the labour force enroled in training courses;

- the proportion of apprenticeship labour in the labour volume of industrial sectors.

The fourth indicator (the labour-market situation for the technically skilled) could not be updated this year because van Paridon did not provide the necessary figures. For this reason the most recently updated version of this indicator has been copied from last year's report.

As mentioned in the 1990 report, the key indicators have to satisfy the following conditions. They should be as relevant to the various aspects of the General Technology Policy as practicable. Input and output indicators should more or less balance each other. Some indicators should give an insight into the social aspects of technological advance. For the sake of international comparison, indicators should be applicable for other countries as well. Finally, the data sources underlying the indicators should guarantee some degree of continuity. The conditions of international comparability and continuity, in particular, have been given full attention in writing this year's report, as in previous reports.

In presenting the updated key indicators, broadly the same classification is used as last year. Section 2.2 discusses two indicators of the contribution of initial education to the breeding ground for technological advance, namely the relative participation in dual education and the share of vocational education in total regular education. The indicator 'share of technically skilled people in the total number of school-leavers and in the labour force', presented in section 2.3, measures how far the contemporary (potential) labour force functions as a breeding ground for technological advance, and measures the dynamics of the breeding ground for technological progress. Section 2.4 presents two indicators measuring the necessity of training to overcome present or possible future impediments to the further diffusion of technological progress. These indicators are the labour market situation for the technically educated and the age composition of the (economically active) population. Finally, section 2.5 presents two indicators of the training efforts being made in response to such obstacles, namely the proportion of the labour force enroled in training courses and the number of apprenticeship agreements per industrial sector, expressed as a proportion of the labour volume of the sector. 


\subsection{Initial education}

\subsubsection{Dual education}

Dual education is the collective name for types of education that combine learning and working, thus providing the students with basic skills for their future careers. In the Netherlands, most dual education takes the form of apprenticeships. The participation of young people in dual education, as already pointed out in De Grip and Nusselder (1989), can be considered indicative of the scientific and technological breeding ground for, in particular, the diffusion of technological advance.

The number of students in dual education can be calculated from the results of the annual 'Labour Force Survey', carried out by Eurostat. In that survey, persons between the ages of 15 and 50 were asked to state the type and purpose of any training course' they had been engaged in during the four weeks preceding the survey. Like last year, we related the number of the persons participating in dual education to ILO figures from the 'Yearbook of Labour Statistics' on the total number of persons in the 15-24 age bracket. This makes a comparison among countries possible.

Table 1. Proportion of dual-system students in total population between the ages of 15 and $24 ; 1983-90$

\begin{tabular}{|c|c|c|c|c|c|c|c|c|}
\hline & $\begin{array}{r}1983 \\
\%\end{array}$ & $\begin{array}{r}1984 \\
\%\end{array}$ & $\begin{array}{r}1985 \\
\%\end{array}$ & $\begin{array}{r}1986 \\
\%\end{array}$ & $\begin{array}{r}1987 \\
\%\end{array}$ & $\begin{array}{r}1988 \\
\%\end{array}$ & $\begin{array}{r}1989 \\
\%\end{array}$ & $\begin{array}{r}1990 \\
\%\end{array}$ \\
\hline The Netherlands & 2.5 & 2.4 & 2.3 & 2.3 & 2.3 & 1.9 & 1.7 & -- \\
\hline France & 2.6 & 2.6 & 2.5 & 2.4 & 2.6 & 2.8 & 2.9 & 8.4 \\
\hline (West) Germany & 10.0 & 13.5 & 15.5 & 17.7 & 17.4 & 17.7 & 17.5 & 18.7 \\
\hline United Kingdom & 7.6 & 5.0 & 5.6 & 4.8 & 4.9 & 5.3 & 5.7 & 5.5 \\
\hline Italy & 0.5 & 0.6 & 0.5 & 0.6 & 0.6 & 0.6 & 0.8 & 0.8 \\
\hline Belgium & 2.3 & 1.9 & 1.8 & 1.9 & 1.6 & 1.3 & 1.5 & 2.8 \\
\hline Luxemburg & 5.8 & 6.3 & 7.0 & 6.1 & 5.7 & 5.1 & 4.8 & 5.1 \\
\hline Ireland & 2.8 & 2.2 & 2.5 & 2.0 & 1.9 & -- & 2.0 & 2.1 \\
\hline Denmark & 7.4 & 18.8 & 22.1 & 22.7 & 23.7 & 23.8 & 20.4 & 20.1 \\
\hline Greece & 0.3 & 0.3 & 0.4 & 0.5 & 0.3 & 0.3 & 0.3 & 0.4 \\
\hline
\end{tabular}

Source: Eurostat/LO/ROA

Legend: -- = not available

The data of table 1 may be slightly distorted by shifts in the non-response to the survey, and should therefore be interpreted with some caution. Nevertheless it is clear that dual education is much more important in Denmark (despite the decrease after 1988) and West Germany than in the other countries investigated. The Netherlands are clearly at the lower end of the scale. The decrease in the percentage for the Netherlands which started in 1988 continued in 1989.

1. This survey makes a distinction between "apprenticeship" (learning contract) and other types of dual education. 
Unfortunately the Labour Force Survey did not contain figures on the participation in dual education in 1990 for the Netherlands. The increase in Belgium, starting in 1989 and strongly continuing in 1990, is related to a strong decrease in the 15-24 age bracket and a substantial increase of participation in apprenticeship education. The slight recovery which started in the second half of the eighties in France continues. The strong French increase in 1990 is related not only to a strong increase of participation in apprenticeship education, but also to the fact that the 'dual system' is no longer categorised under the heading 'other' and is as a consequence included for the first time in the calculation of the indicator. The recovery in the United Kingdom seems to be stagnating. By contrast, in Luxemburg the declining tendency noticeable after 1985 continues in 1990. Ireland, Italy and Greece show a stable low picture. For the time being this indicator is only available for the EC countries.

\subsubsection{Share of vocational education in total regular education}

This sub-section's indicator represents the share of vocational students (second and third levels ${ }^{2}$ ) in the total number of second and third-level students. On the basis of the 'Statistical Yearbook' of UNESCO a division into vocational and general education is possible. To compose the indicator we have counted all third-level education (Higher Education) as vocational education.

This ratio indicates in particular the degree to which people in their later careers are open to technological advance. The underlying assumption is that workers with a broad initial vocational education tend to be more responsive to innovations than workers who have gained their skill in practice; the latter tend in particular to fall short on theoretical knowledge. Therefore, this indicator can be considered representative of the state of the scientific and technological breeding ground for the diffusion of technological change. Possibly a higher share of vocational education can also be considered to add to the society's innovative potential.

Table 2. Indicator of the share of vocational education (second and third levels); 1975, 1980-89

\begin{tabular}{|c|c|c|c|c|c|c|c|c|c|c|c|}
\hline & $\begin{array}{r}1975 \\
\%\end{array}$ & $\begin{array}{r}1980 \\
\%\end{array}$ & $\begin{array}{r}1981 \\
\%\end{array}$ & $\begin{array}{r}1982 \\
\%\end{array}$ & $\begin{array}{r}1983 \\
\%\end{array}$ & $\begin{array}{r}1984 \\
\%\end{array}$ & $\begin{array}{r}1985 \\
\%\end{array}$ & $\begin{array}{r}1986 \\
\%\end{array}$ & $\begin{array}{r}1987 \\
\%\end{array}$ & $\begin{array}{r}1988 \\
\%\end{array}$ & $\begin{array}{r}1989 \\
\%\end{array}$ \\
\hline The Netherlands & 51 & 53 & 53 & 54 & 55 & 55 & 56 & 57 & 57 & 51 & - \\
\hline France & 35 & 36 & 36 & 40 & 38 & 39 & 36 & 40 & 38 & 39 & 40 \\
\hline (West) Germany & 32 & 33 & 35 & 37 & 29 & 31 & 32 & 48 & 49 & 50 & -- \\
\hline United Kingdom & 16 & 18 & 19 & 19 & 20 & 23 & 24 & 26 & 27 & 28 & -- \\
\hline Sweden & 45 & 45 & 46 & 49 & 51 & 51 & - & 50 & 50 & 51 & 51 \\
\hline Austria & 25 & 33 & 33 & 35 & 37 & 40 & 41 & 43 & 43 & 44 & 45 \\
\hline United States & -- & -- & -- & -- & -- & -- & -- & - & -- & -- & - \\
\hline Japan & 34 & 32 & 32 & 30 & 30 & 29 & 28 & 28 & 28 & 29 & 30 \\
\hline
\end{tabular}

Source: UNESCO/ROA

Legend: -- = not available

2. The second and third levels comprise all education beyond the elementary stage. 
Table 2 shows that the Netherlands, Sweden and West Germany have the highest proportion of students in vocational education, whereas in the United Kingdom and Japan it is much lower. Over the last three years (1987-1989) the share of vocational education has increased in all countries, except in the Netherlands and in Sweden. In the Netherlands the rising tendency since 1975 seems to end in 1988. In Sweden the indicator remains stable at a high level. In West Germany, the United Kingdom and Austria this indicator continues to show a rising tendency. The sharp increase in 1986 as compared with 1985 in West Germany is due to a change in the definition of 'vocational training'. The steadily declining tendency in Japan has from 1988 on turned into a rising tendency.

\subsection{Labour force and school-leavers}

2.3.1. Share of technically skilled persons in the total number of school-leavers and in the labour force

Table 3. Share of technically trained (school-leavers and labour force); 1982/83-2008/09

\begin{tabular}{|c|c|c|c|c|}
\hline & $\begin{array}{c}\text { School-leavers } \\
\%^{1}\end{array}$ & & $\begin{array}{l}\text { Labour force } \\
\%^{2}\end{array}$ & $\begin{array}{c}\text { Indicator } \\
\%^{3}\end{array}$ \\
\hline $1982 / 1983$ & 21.8 & & 20.8 & 105 \\
\hline $1983 / 1984$ & 22.1 & & 21.0 & 105 \\
\hline $1984 / 1985$ & 22.1 & & 21.3 & 104 \\
\hline $1985 / 1986$ & 21.8 & & 21.6 & 101 \\
\hline $1986 / 1987$ & 21.7 & & 21.8 & 100 \\
\hline $1987 / 1988$ & 21.2 & & 22.0 & 96 \\
\hline $1988 / 1989$ & 20.3 & & 22.2 & 92 \\
\hline $1989 / 1990$ & 20.4 & & 22.3 & 92 \\
\hline $1990 / 1991$ & 19.8 & & 22.4 & 88 \\
\hline $1991 / 1992$ & 19.9 & $21.7^{4}$ & 22.5 & 88 \\
\hline $1992 / 1993$ & 20.1 & 21.6 & 22.6 & 89 \\
\hline $1993 / 1994$ & 20.2 & 21.5 & 22.7 & 89 \\
\hline $1994 / 1995$ & 20.2 & 21.1 & 22.8 & 89 \\
\hline $1995 / 1996$ & 20.1 & 20.7 & 22.9 & 88 \\
\hline $1996 / 1997$ & 20.0 & 20.3 & 22.9 & 87 \\
\hline $1997 / 1998$ & & 20.0 & & \\
\hline $1998 / 1999$ & & 19.6 & & \\
\hline $1999 / 2000$ & & 19.5 & & \\
\hline $2000 / 2001$ & 19.6 & 19.4 & 23.0 & 85 \\
\hline $2001 / 2002$ & & 19.4 & & \\
\hline $2002 / 2003$ & & 19.4 & & \\
\hline $2003 / 2004$ & & 19.4 & & \\
\hline $2004 / 2005$ & & 19.3 & & \\
\hline $2005 / 2006$ & & 19.2 & & \\
\hline $2006 / 2007$ & & 19.2 & & \\
\hline $2007 / 2008$ & & 19.3 & & \\
\hline $2008 / 2009$ & & 19.3 & & \\
\hline
\end{tabular}

Source: MOW $(1990,1991) / R O A$ 
Legend:

$1=$ Share of technically trained school-leavers in the cohort.

$2=$ Share of technically trained workers in the labour force.

$3=$ Ratio of proportion of school-leavers with technical education to proportion of the labour force having a technical education.

$4=$ This column has been included because the figures in the first column, based on the 'SKILL forecasts' of the MOW, related to persons in the 0-50 age bracket. The figures in the second column are based on the new 'Referentieraming' of the MOW and relate to persons in the 15-64 age bracket.

$5=$ These two (sub)indicators cannot be calculated because the new 'Referentieraming', unlike the former 'SKILL forecasts', does not provide data on the education of the labour force.

This section presents two sub-indicators of the share of technically educated persons in the most recent group of school-leavers, and in the labour force. A similar indicator relates the proportion of technically educated school-leavers to the potential labour force. As indicated in the 1990 report (see Van Dam and de Grip, 1990), the share of technically educated persons in the labour force measures the health of the scientific and technological breeding ground of society in terms of innovation as well as diffusion. The sub-indicator referring to school-leavers and, especially, the indicator relating the number of technically educated persons among schoolleavers and the potential labour force (column 3 of table 3 ) are the more dynamic measures of the evolution of this breeding ground.

Last year this indicator was not updated because the annual 'SKILL' forecasts of the MOW, which were used for updating this indicator, were in 1991 replaced by the so called 'Referentieraming' of the MOW. The release date of this forecast was so late that ROA could not properly incorporate it. This year the 'Referentieraming' is for the first time used to update this indicator.

The updated sub-indicator in the first column in table 3 shows a declining tendency in the share of the technically educated in the classes of school-leavers in the 1990s. As already indicated in the 1990 report (Van Dam and de Grip, 1990) the inflow of school-leavers since 1986/87 is gradually reducing the share of the technically educated in the potential labour force (after $1986 / 87$ the indicator in the third column dropped to below one hundred).

\subsection{The need for training}

\subsubsection{Labour market situation for the technically educated: tension indicators}

Van Paridon has developed an indicator of bottlenecks on the labour market for technically educated persons representing the proportion of school-leavers of the most recent cohort who are still unemployed. It relies on unemployment figures of the District Labour Exchanges, corrected for "file corruption"3. The indicator thus obtained is, as said before, a criterion by which to identify obstacles to the diffusion of technological advance in certain segments of the labour market. Because van Paridon did not provide the 1992 figures necessary for updating

3. Following Van Paridon we assume that the file corruption among schoolleavers is great (60 per cent), because many remain on the registers while working in temporary jobs, whether or not acquired through an employment agency. 
this indicator, table 4 and the accompanying comments are copied from last year's report.

Table 4. Unemployment rates among school-leavers (May figures); 1986-91

\begin{tabular}{|c|c|c|c|c|c|c|}
\hline & 1986 & 1987 & 1988 & 1989 & 1990 & 1991 \\
\hline $\begin{array}{l}\text {-Lower Vocational Education } \\
\text { Lower Technical Schools }\end{array}$ & $\begin{array}{l}19 \\
13\end{array}$ & $\begin{array}{l}15 \\
10\end{array}$ & $\begin{array}{l}15 \\
10\end{array}$ & $\begin{array}{l}14 \\
10\end{array}$ & $\begin{array}{r}13 \\
8\end{array}$ & $\begin{array}{l}8 \\
4\end{array}$ \\
\hline $\begin{array}{l}\text {-Intermediate Vocational Education } \\
\text { Intermediate Technical Schools } \\
\text { Mechancial Engineering } \\
\text { Energy Technics } \\
\text { Electronics } \\
\text { Process Technics }\end{array}$ & $\begin{array}{l}9 \\
5 \\
4 \\
2 \\
6 \\
4\end{array}$ & $\begin{array}{l}8 \\
4 \\
3 \\
2 \\
5 \\
5\end{array}$ & $\begin{array}{r}10 \\
4 \\
4 \\
3 \\
6 \\
8\end{array}$ & $\begin{array}{r}10 \\
5 \\
4 \\
3 \\
7 \\
8\end{array}$ & $\begin{array}{l}7 \\
3 \\
2 \\
3 \\
3 \\
5\end{array}$ & $\begin{array}{l}4 \\
2 \\
2 \\
2 \\
2 \\
2 \\
2\end{array}$ \\
\hline $\begin{array}{l}\text {-Higher Vocational Education } \\
\text { Higher Technical Schools } \\
\text { Electrotechnics } \\
\text { Informatica } \\
\text { Mechanical Engineering } \\
\text { Business Administration }\end{array}$ & $\begin{array}{r}12 \\
4 \\
3 \\
2 \\
2 \\
2\end{array}$ & $\begin{array}{r}10 \\
4 \\
2 \\
3 \\
2 \\
4\end{array}$ & $\begin{array}{r}12 \\
5 \\
6 \\
3 \\
4 \\
4\end{array}$ & $\begin{array}{r}11 \\
5 \\
8 \\
6 \\
4 \\
3\end{array}$ & $\begin{array}{l}9 \\
4 \\
6 \\
5 \\
2 \\
4\end{array}$ & $\begin{array}{l}6 \\
2 \\
3 \\
3 \\
1 \\
3\end{array}$ \\
\hline $\begin{array}{l}\text {-Academic Education } \\
\text { Technical Sciences } \\
\text { Electrotechnics } \\
\text { Mathematics } \\
\text { Informatica } \\
\text { Business Administration }\end{array}$ & $\begin{array}{r}11 \\
6 \\
3 \\
3 \\
- \\
7\end{array}$ & $\begin{array}{r}10 \\
5 \\
1 \\
4 \\
3 \\
2\end{array}$ & $\begin{array}{l}9 \\
5 \\
4 \\
6 \\
2 \\
3\end{array}$ & $\begin{array}{r}12 \\
6 \\
5 \\
6 \\
3 \\
3\end{array}$ & $\begin{array}{l}7 \\
4 \\
3 \\
3 \\
4 \\
7\end{array}$ & $\begin{array}{l}4 \\
3 \\
3 \\
1 \\
3 \\
1\end{array}$ \\
\hline Total & 14 & 11 & 12 & 12 & 11 & 8 \\
\hline
\end{tabular}

Source: Van Paridon/ROA

Table 4 displays the employment situation in the years between 1986 and 1991. As can be observed, the decline in unemployment after 1989 continued in 1991. In 1991, in a tightening but still relatively easy general labour market, the situation for those with a technical education has become even tighter. That points to an improvement in the labour-market position of those with a non-technical education. In particular unemployment among non-technical university graduates has declined further since 1989. One striking fact is the improvement in the labour market situation of university-educated commerce graduates, which has become very favourable to work seekers in 1991.

Regrettably, no internationally comparable data could be traced in any publications of international organisations or national statistic bureaus.

\subsubsection{Age composition of the (active) population}

Two indicators represent the age composition of, respectively, the total population and the 
economically active population (labour force) ${ }^{4}$. These indicators measure the declining share of the young and the increasing share of the aged in, respectively, the total and the economically active population. To comply with the wishes of the Ministry of Economic Affairs, we will give an overall picture of the age composition of the (active) population rather than specific indicators of either share. The two indicators representing the age composition of the total and economically active populations are calculated on the basis of figures from the OECD's 'Labour Force Statistics' and the ILO's 'Yearbook of Labour Statistics'.

The share of 'senior citizens' in the active population can be considered as a measure of the need for training on the assumption that, as technological progress renders the labour force's initial training obsolete, retraining becomes necessary to the productive re-employment of the workers involved. In other words: the indicator measures the 'vulnerability' of the labour force to technological progress. It is also a measure of the 'intra-generational mobility' (De Grip, 1987) required to overcome any shifts which technological advance should cause in the occupational structure. The drop in the proportion of young people (15-24) in the active and overall population indicates the society's ability to respond to the changed educational requirements due to technological progress by adjusting initial education to practical demands. Indeed, the adjustment of initial education to the developments on the labour market will have less effect as the proportion of young people in the labour force is lower.

Table 5 shows the size of the four age groups distinguished as proportions of the total population. As can be seen the Netherlands, West Germany, the United Kingdom, Austria and the United States experience a declining proportion of the 15-24 year age bracket in recent years, while Japan has experienced a growing proportion of young people. The lowest proportion of the 15-24 year age bracket however is still to be found in Sweden. In the United States the declining tendency in the proportion of young people seems to have come to an end.

Among the European countries the population of West Germany has the largest group of over50s. Japan is the only country that is experiencing at the same time a growing proportion of the youngest age brackets and of the older age groups.

Table 6 represents the shares of the same four age groups in the economically active population. This table shows that the United States, Austria and the Netherlands have a relatively young active population, whereas in Japan the share of the over-65 in the active population is relatively high. A striking feature is the relatively high proportion of active people between the ages of 50 and 65 in Japan, Sweden and West Germany. That group's share is even increasing in Japan and West Germany over the last years. The lowest proportion of people between the ages of 50 and 65 in the active population is to be found in the Netherlands and Austria where

4. The ILO defines the economically active population as all persons providing the supply of labour for the production of goods and services. Both employed and unemployed persons belong to the active population. Students, retired persons and women not participating in the labour market, on the contrary, do not come under the definition. 
moreover it declined considerably in the 1980s. The same pattern, though somewhat less marked, applies to most other countries.

The 1990 report (see Van Dam and De Grip, 1990) also included forecasts of the future share of senior citizens in the Dutch (potential) labour force. Such forecasts have in 1989 been drawn up for the age structures of the total population and the potential labour force (between the ages of 15 and 65 ) in the Netherlands. The forecasts neatly showed the expected declining proportion of the younger age brackets and the expanding share of the older ones. It was calculated that the proportion of young people (between 15 and 24 years old) in the potential labour force is expected to drop from 23.0 per cent in 1990 to only 17.4 per cent in 2005, after which it is expected to increase again slightly. By contrast, a clear increase in the share of the older age brackets $(15-65)$ in the potential labour force is perceived: from 21.2 per cent in 1990 to 28.0 per cent in 2005. Presumably, the process of aging will continue to around 2030.

Table 5. Percentage shares of age groups in total population; $1980-90$

\begin{tabular}{|c|c|c|c|c|c|c|c|c|c|c|c|c|}
\hline & age & $\begin{array}{r}1980 \\
\%\end{array}$ & $\begin{array}{r}1981 \\
\%\end{array}$ & $\begin{array}{r}1982 \\
\%\end{array}$ & $\begin{array}{r}1983 \\
\%\end{array}$ & $\begin{array}{r}1984 \\
\%\end{array}$ & $\begin{array}{r}1985 \\
\%\end{array}$ & $\begin{array}{r}1986 \\
\%\end{array}$ & $\begin{array}{r}1987 \\
\%\end{array}$ & $\begin{array}{r}1988 \\
\%\end{array}$ & $\begin{array}{r}1989 \\
\%\end{array}$ & $\begin{array}{r}1990 \\
\%\end{array}$ \\
\hline The Netherlands & $\begin{array}{l}15-24 \\
25-49 \\
50-65 \\
65+-\end{array}$ & $\begin{array}{l}17.3 \\
34.2 \\
14.4 \\
11.5\end{array}$ & $\begin{array}{l}17.4 \\
34.5 \\
14.5 \\
11.6\end{array}$ & $\begin{array}{l}17.4 \\
35.2 \\
14.5 \\
11.7\end{array}$ & $\begin{array}{l}17.3 \\
35.2 \\
14.6 \\
11.7\end{array}$ & $\begin{array}{l}17.3 \\
35.1 \\
14.6 \\
11.7\end{array}$ & $\begin{array}{l}-- \\
-- \\
-- \\
-\end{array}$ & $\begin{array}{l}17.2 \\
36.5 \\
14.7 \\
12.2\end{array}$ & $\begin{array}{l}16.9 \\
37.4 \\
14.8 \\
12.5\end{array}$ & $\begin{array}{r}16.6 \\
37.9 \\
14.7 \\
--\end{array}$ & $\begin{array}{r}16.2 \\
38.4 \\
14.6 \\
--\end{array}$ & $\begin{array}{r}15.7 \\
38.7 \\
14.7 \\
--\end{array}$ \\
\hline France & $\begin{array}{l}15-24 \\
25-49 \\
50-65 \\
65+-\end{array}$ & $\begin{array}{l}15.9 \\
33.3 \\
15.3 \\
14.5\end{array}$ & $\begin{array}{l}15.8 \\
33.4 \\
15.8 \\
14.2\end{array}$ & $\begin{array}{l}15.7 \\
33.5 \\
16.2 \\
13.9\end{array}$ & $\begin{array}{l}15.6 \\
33.7 \\
16.6 \\
13.7\end{array}$ & $\begin{array}{l}15.6 \\
33.3 \\
16.7 \\
13.4\end{array}$ & $\begin{array}{l}15.6 \\
34.1 \\
16.5 \\
13.7\end{array}$ & $\begin{array}{l}15.5 \\
34.4 \\
16.4 \\
13.9\end{array}$ & $\begin{array}{l}15.1 \\
35.0 \\
16.4 \\
13.8\end{array}$ & $\begin{array}{l}15.9 \\
35.9 \\
15.8 \\
14.9\end{array}$ & $\begin{array}{l}15.2 \\
35.3 \\
16.0 \\
14.8\end{array}$ & $\begin{array}{l}-- \\
-- \\
--\end{array}$ \\
\hline (West) Germany & $\begin{array}{l}15-24 \\
25-49 \\
50-65 \\
65+-\end{array}$ & $\begin{array}{l}15.6 \\
34.1 \\
16.2 \\
15.9\end{array}$ & $\begin{array}{l}16.1 \\
34.2 \\
16.6 \\
15.6\end{array}$ & $\begin{array}{l}16.3 \\
34.4 \\
17.1 \\
15.4\end{array}$ & $\begin{array}{l}16.7 \\
35.3 \\
17.3 \\
14.2\end{array}$ & $\begin{array}{l}16.7 \\
35.2 \\
18.1 \\
15.0\end{array}$ & $\begin{array}{l}16.5 \\
35.2 \\
18.4 \\
15.2\end{array}$ & $\begin{array}{l}16.3 \\
35.4 \\
18.4 \\
15.4\end{array}$ & $\begin{array}{l}15.7 \\
35.6 \\
18.6 \\
15.7\end{array}$ & $\begin{array}{l}15.0 \\
35.6 \\
18.9 \\
16.0\end{array}$ & $\begin{array}{l}14.3 \\
36.0 \\
19.1 \\
16.0\end{array}$ & $\begin{array}{l}-- \\
-- \\
--\end{array}$ \\
\hline United Kingdom & $\begin{array}{l}15-24 \\
25-49 \\
50-65 \\
65+-\end{array}$ & $\begin{array}{l}-- \\
-- \\
-- \\
-\end{array}$ & $\begin{array}{l}15.8 \\
31.8 \\
16.8 \\
14.8\end{array}$ & $\begin{array}{l}-- \\
-- \\
-- \\
--\end{array}$ & $\begin{array}{l}-- \\
-- \\
- \\
-\end{array}$ & $\begin{array}{l}-- \\
-- \\
--\end{array}$ & $\begin{array}{l}-- \\
-- \\
--\end{array}$ & $\begin{array}{l}16.3 \\
33.2 \\
16.2 \\
15.3\end{array}$ & $\begin{array}{l}-- \\
-- \\
-- \\
--\end{array}$ & $\begin{array}{l}15.7 \\
33.9 \\
15.9 \\
15.6\end{array}$ & $\begin{array}{l}- \\
-- \\
--\end{array}$ & $\begin{array}{l}-- \\
-- \\
-- \\
-\end{array}$ \\
\hline Sweden & $\begin{array}{l}15-24 \\
25-49 \\
50-65 \\
65+-\end{array}$ & $\begin{array}{l}12.0 \\
33.4 \\
17.3 \\
16.6\end{array}$ & $\begin{array}{l}-- \\
-- \\
--\end{array}$ & $\begin{array}{l}12.3 \\
33.7 \\
17.0 \\
10.0\end{array}$ & $\begin{array}{r}12.5 \\
34.0 \\
16.8 \\
9.9\end{array}$ & $\begin{array}{r}12.6 \\
34.2 \\
16.6 \\
9.9\end{array}$ & $\begin{array}{l}12.6 \\
34.4 \\
16.3 \\
10.0\end{array}$ & $\begin{array}{r}12.6 \\
34.3 \\
16.2 \\
--\end{array}$ & $\begin{array}{r}12.7 \\
34.8 \\
15.7 \\
--\end{array}$ & $\begin{array}{l}-- \\
-- \\
-- \\
-\end{array}$ & $\begin{array}{r}12.5 \\
35.0 \\
15.3 \\
--\end{array}$ & $\begin{array}{r}12.4 \\
35.2 \\
15.2 \\
-\end{array}$ \\
\hline Austria & $\begin{array}{l}15-24 \\
25-49 \\
50-65 \\
65+-\end{array}$ & $\begin{array}{l}14.4 \\
34.0 \\
15.6 \\
15.5\end{array}$ & $\begin{array}{l}16.7 \\
32.3 \\
15.8 \\
15.2\end{array}$ & $\begin{array}{l}16.7 \\
32.6 \\
16.2 \\
14.9\end{array}$ & $\begin{array}{l}16.6 \\
33.3 \\
16.5 \\
14.4\end{array}$ & $\begin{array}{l}17.0 \\
33.5 \\
16.7 \\
14.3\end{array}$ & $\begin{array}{l}16.9 \\
34.0 \\
16.6 \\
14.4\end{array}$ & $\begin{array}{l}16.7 \\
34.6 \\
16.3 \\
14.5\end{array}$ & $\begin{array}{l}16.3 \\
35.3 \\
16.0 \\
14.7\end{array}$ & $\begin{array}{l}15.9 \\
35.9 \\
15.8 \\
14.9\end{array}$ & $\begin{array}{l}15.4 \\
36.2 \\
15.8 \\
15.1\end{array}$ & $\begin{array}{l}-- \\
-- \\
-- \\
--\end{array}$ \\
\hline United States & $\begin{array}{l}15-24 \\
25-49 \\
50-65 \\
65+-\end{array}$ & $\begin{array}{l}16.9 \\
32.4 \\
14.7 \\
11.2\end{array}$ & $\begin{array}{l}17.3 \\
33.2 \\
14.6 \\
11.4\end{array}$ & $\begin{array}{l}19.5 \\
33.9 \\
14.4 \\
11.6\end{array}$ & $\begin{array}{l}-- \\
-- \\
--\end{array}$ & $\begin{array}{l}17.0 \\
35.1 \\
14.1 \\
11.9\end{array}$ & $\begin{array}{l}16.6 \\
35.8 \\
13.9 \\
11.9\end{array}$ & $\begin{array}{l}16.2 \\
36.4 \\
13.7 \\
12.1\end{array}$ & $\begin{array}{l}15.7 \\
37.0 \\
13.5 \\
12.3\end{array}$ & $\begin{array}{l}15.2 \\
37.4 \\
13.4 \\
12.4\end{array}$ & $\begin{array}{l}13.5 \\
38.1 \\
13.4 \\
12.6\end{array}$ & $\begin{array}{l}14.7 \\
37.8 \\
13.3 \\
12.5\end{array}$ \\
\hline Japan & $\begin{array}{l}15-24 \\
25-49 \\
50-65 \\
65+-\end{array}$ & $\begin{array}{r}13.8 \\
38.9 \\
14.7 \\
9.1\end{array}$ & $\begin{array}{r}13.6 \\
38.6 \\
15.1 \\
9.3\end{array}$ & $\begin{array}{r}13.7 \\
38.2 \\
15.5 \\
9.5\end{array}$ & $\begin{array}{r}13.8 \\
37.8 \\
16.0 \\
9.7\end{array}$ & $\begin{array}{r}14.0 \\
37.6 \\
16.4 \\
9.9\end{array}$ & $\begin{array}{l}14.2 \\
37.2 \\
16.8 \\
10.2\end{array}$ & $\begin{array}{l}14.4 \\
36.9 \\
17.2 \\
10.5\end{array}$ & $\begin{array}{l}14.7 \\
36.5 \\
17.5 \\
10.8\end{array}$ & $\begin{array}{l}15.0 \\
36.3 \\
17.8 \\
11.2\end{array}$ & $\begin{array}{l}15.2 \\
36.2 \\
18.0 \\
11.5\end{array}$ & $\begin{array}{l}15.3 \\
36.2 \\
18.2 \\
12.0\end{array}$ \\
\hline
\end{tabular}


Table 6. Percentage shares of age groups in active population; $1980-90$

\begin{tabular}{|c|c|c|c|c|c|c|c|c|c|c|c|c|}
\hline & age & $\begin{array}{r}1980 \\
\%\end{array}$ & $\begin{array}{r}1981 \\
\%\end{array}$ & $\begin{array}{r}1982 \\
\%\end{array}$ & $\begin{array}{r}1983 \\
\%\end{array}$ & $\begin{array}{r}1984 \\
\%\end{array}$ & $\begin{array}{r}1985 \\
\%\end{array}$ & $\begin{array}{r}1986 \\
\%\end{array}$ & $\begin{array}{r}1987 \\
\%\end{array}$ & $\begin{array}{r}1988 \\
\%\end{array}$ & $\begin{array}{r}1989 \\
\%\end{array}$ & $\begin{array}{r}1990 \\
\%\end{array}$ \\
\hline The Netherlands & $\begin{array}{l}15-24 \\
25-49 \\
50-65 \\
65+-\end{array}$ & $\begin{array}{r}21.6 \\
59.7 \\
17.2 \\
0.5\end{array}$ & $\begin{array}{r}22.0 \\
61.0 \\
16.3 \\
0.7\end{array}$ & $\begin{array}{r}21.5 \\
62.1 \\
15.7 \\
0.6\end{array}$ & $\begin{array}{r}21.6 \\
62.2 \\
15.6 \\
0.7\end{array}$ & $\begin{array}{r}21.6 \\
62.2 \\
15.6 \\
0.7\end{array}$ & $\begin{array}{l}-- \\
-- \\
--\end{array}$ & $\begin{array}{r}20.2 \\
64.6 \\
14.7 \\
0.6\end{array}$ & $\begin{array}{r}22.4 \\
63.1 \\
13.6 \\
1.0\end{array}$ & $\begin{array}{r}22.0 \\
64.5 \\
13.5 \\
--\end{array}$ & $\begin{array}{r}21.3 \\
65.3 \\
13.4 \\
---\end{array}$ & $\begin{array}{r}20.9 \\
65.8 \\
13.3 \\
--\end{array}$ \\
\hline France & $\begin{array}{l}15-24 \\
25-49 \\
50-65 \\
65+-\end{array}$ & $\begin{array}{r}17.2 \\
60.4 \\
21.0 \\
1.4\end{array}$ & $\begin{array}{r}16.8 \\
61.0 \\
21.0 \\
1.2\end{array}$ & $\begin{array}{r}16.7 \\
61.7 \\
20.7 \\
0.9\end{array}$ & $\begin{array}{r}16.3 \\
62.7 \\
20.1 \\
0.9\end{array}$ & $\begin{array}{r}16.0 \\
63.4 \\
19.6 \\
0.9\end{array}$ & $\begin{array}{r}15.8 \\
64.1 \\
19.2 \\
0.9\end{array}$ & $\begin{array}{r}15.3 \\
65.0 \\
18.9 \\
0.9\end{array}$ & $\begin{array}{r}13.6 \\
66.6 \\
18.9 \\
0.9\end{array}$ & $\begin{array}{l}-- \\
-- \\
--\end{array}$ & $\begin{array}{r}13.3 \\
67.3 \\
18.5 \\
0.8\end{array}$ & $\begin{array}{l}-- \\
-- \\
--\end{array}$ \\
\hline (West) Germany & $\begin{array}{l}15-24 \\
25-49 \\
50-65 \\
65+-\end{array}$ & $\begin{array}{r}20.6 \\
58.1 \\
19.6 \\
1.6\end{array}$ & $\begin{array}{r}20.8 \\
57.9 \\
19.8 \\
1.5\end{array}$ & $\begin{array}{r}20.7 \\
58.0 \\
20.0 \\
1.3\end{array}$ & $\begin{array}{r}20.8 \\
58.4 \\
19.6 \\
1.3\end{array}$ & $\begin{array}{r}21.1 \\
58.1 \\
19.6 \\
1.2\end{array}$ & $\begin{array}{r}21.2 \\
58.2 \\
19.5 \\
1.1\end{array}$ & $\begin{array}{r}20.9 \\
58.2 \\
19.9 \\
1.0\end{array}$ & $\begin{array}{r}20.2 \\
58.4 \\
20.3 \\
1.0\end{array}$ & $\begin{array}{r}19.5 \\
58.6 \\
21.0 \\
1.0\end{array}$ & $\begin{array}{r}18.3 \\
59.6 \\
21.3 \\
0.9\end{array}$ & $\begin{array}{l}-- \\
-- \\
--\end{array}$ \\
\hline United Kingdom & $\begin{array}{l}15-24 \\
25-49 \\
50-65 \\
65+-\end{array}$ & $\begin{array}{l}-- \\
-- \\
--\end{array}$ & $\begin{array}{r}21.0 \\
53.3 \\
23.6 \\
2.0\end{array}$ & $\begin{array}{l}- \\
-- \\
-- \\
--\end{array}$ & $\begin{array}{l}-- \\
-- \\
--\end{array}$ & $\begin{array}{l}-- \\
-- \\
--\end{array}$ & $\begin{array}{l}-- \\
- \\
- \\
-\end{array}$ & $\begin{array}{r}22.9 \\
55.3 \\
20.3 \\
1.5\end{array}$ & $\begin{array}{l}- \\
-- \\
-- \\
--\end{array}$ & $\begin{array}{r}22.3 \\
56.4 \\
19.8 \\
1.5\end{array}$ & $\begin{array}{l}-- \\
-- \\
--\end{array}$ & $\begin{array}{l}-- \\
-- \\
-\end{array}$ \\
\hline Sweden & $\begin{array}{l}15-24 \\
25-49 \\
50-65 \\
65+-\end{array}$ & $\begin{array}{r}14.5 \\
58.5 \\
25.3 \\
1.7\end{array}$ & $\begin{array}{l}-- \\
-- \\
--\end{array}$ & $\begin{array}{r}15.7 \\
58.5 \\
24.2 \\
1.6\end{array}$ & $\begin{array}{r}15.5 \\
59.1 \\
23.9 \\
1.5\end{array}$ & $\begin{array}{r}15.5 \\
59.7 \\
23.5 \\
1.3\end{array}$ & $\begin{array}{r}15.7 \\
60.1 \\
22.9 \\
1.3\end{array}$ & $\begin{array}{r}16.2 \\
60.4 \\
23.4 \\
--\end{array}$ & $\begin{array}{r}16.0 \\
61.3 \\
22.7 \\
--\end{array}$ & $\begin{array}{l}-- \\
-- \\
-- \\
--\end{array}$ & $\begin{array}{r}16.3 \\
61.5 \\
22.1 \\
--\end{array}$ & $\begin{array}{r}15.8 \\
61.9 \\
22.3 \\
--\end{array}$ \\
\hline Austria & $\begin{array}{l}15-24 \\
25-49 \\
50-65 \\
65+-\end{array}$ & $\begin{array}{r}19.7 \\
59.8 \\
19.8 \\
0.7\end{array}$ & $\begin{array}{r}25.4 \\
56.5 \\
17.3 \\
0.8\end{array}$ & $\begin{array}{r}23.3 \\
58.2 \\
17.7 \\
0.8\end{array}$ & $\begin{array}{r}23.5 \\
58.9 \\
17.0 \\
0.6\end{array}$ & $\begin{array}{r}24.6 \\
58.5 \\
16.4 \\
0.5\end{array}$ & $\begin{array}{r}24.1 \\
59.8 \\
15.6 \\
0.5\end{array}$ & $\begin{array}{r}23.9 \\
60.7 \\
14.9 \\
0.5\end{array}$ & $\begin{array}{r}23.7 \\
61.4 \\
14.4 \\
0.4\end{array}$ & $\begin{array}{r}22.7 \\
62.7 \\
14.2 \\
0.4\end{array}$ & $\begin{array}{r}21.7 \\
63.5 \\
14.4 \\
0.4\end{array}$ & $\begin{array}{l}-- \\
-- \\
-- \\
--\end{array}$ \\
\hline United States & $\begin{array}{l}15-24 \\
25-49 \\
50-65 \\
65+-\end{array}$ & $\begin{array}{r}23.0 \\
54.6 \\
19.3 \\
3.0\end{array}$ & $\begin{array}{r}23.7 \\
55.2 \\
18.4 \\
2.7\end{array}$ & $\begin{array}{r}22.9 \\
56.3 \\
18.1 \\
2.5\end{array}$ & $\begin{array}{l}-- \\
-- \\
-- \\
--\end{array}$ & $\begin{array}{r}21.1 \\
58.9 \\
17.6 \\
2.2\end{array}$ & $\begin{array}{r}20.2 \\
58.8 \\
17.1 \\
2.5\end{array}$ & $\begin{array}{r}19.8 \\
60.6 \\
17.0 \\
2.6\end{array}$ & $\begin{array}{r}19.2 \\
61.5 \\
16.8 \\
2.6\end{array}$ & $\begin{array}{r}18.3 \\
61.3 \\
16.4 \\
2.7\end{array}$ & $\begin{array}{r}17.6 \\
61.9 \\
16.4 \\
2.7\end{array}$ & $\begin{array}{l}-- \\
-- \\
--\end{array}$ \\
\hline Japan & $\begin{array}{l}15-24 \\
25-49 \\
50-65 \\
65+-\end{array}$ & $\begin{array}{r}12.4 \\
61.6 \\
21.0 \\
4.9\end{array}$ & $\begin{array}{r}12.3 \\
61.3 \\
21.4 \\
5.0\end{array}$ & $\begin{array}{r}12.2 \\
60.9 \\
22.0 \\
5.0\end{array}$ & $\begin{array}{r}12.4 \\
60.1 \\
22.5 \\
5.0\end{array}$ & $\begin{array}{r}12.4 \\
59.8 \\
22.9 \\
5.0\end{array}$ & $\begin{array}{r}12.3 \\
59.3 \\
23.4 \\
5.0\end{array}$ & $\begin{array}{r}12.5 \\
58.6 \\
23.8 \\
5.0\end{array}$ & $\begin{array}{r}12.6 \\
58.1 \\
24.2 \\
5.1\end{array}$ & $\begin{array}{r}12.7 \\
57.5 \\
24.6 \\
5.3\end{array}$ & $\begin{array}{r}12.9 \\
57.1 \\
24.6 \\
5.4\end{array}$ & $\begin{array}{r}13.1 \\
56.5 \\
24.8 \\
5.6\end{array}$ \\
\hline
\end{tabular}

Source: ILO/OECD/ROA

Legend: -- = not available

\subsection{Educational efforts}

\subsubsection{Proportion of the potential labour force in post-elementary education}

Schooling is an important means of responding to technological progress. The 'Labour Force Survey' conducted yearly by Eurostat for the European Community produces data on the respondents' participation in schooling during the four weeks preceding the survey. Persons between the ages of 15 and 50 are asked to state what schooling they were participating in and for what purpose. From this data we can derive the proportion of the potential labour force between the ages of 15 and 50 which participates in schooling. This indicator can be calculated in a narrow and in a wide sense. By schooling in the wide sense is understood 'on-the-job training, apprenticeship, dual system' and 'other training'. So the indicator encompasses all types of schooling that are combined with a job (see table 7). The indicator in the narrow sense (see table 8), on the contrary, is limited to 'on-the-job training', leaving out the more elementary occupational types of training (apprenticeship etc.). To calculate the indicators, the number of 
people who participated in schooling in the four weeks before the survey has been related to the total population in the age brackets between 15 and 49 . These indicators can be counted as measures of the scientific and technological breeding ground for, in particular, the diffusion of technological progress. The indicators presented here do permit comparison with other countries, but for the time being only with EC member states. Unfortunately the 'Labour Force Survey' did not contain figures on the participation in on-the-job training, apprenticeship and dual system education respectively in 1990 for the Netherlands. Figures for France are also not available.

Table 7. Participation in schooling (in the wide sense) as a percentage of the potential labour force between the ages of 15 and $49 ; 1983-90$

\begin{tabular}{|c|c|c|c|c|c|c|c|c|}
\hline & $\begin{array}{r}1983 \\
\%\end{array}$ & $\begin{array}{r}1984 \\
\%\end{array}$ & $\begin{array}{r}1985 \\
\%\end{array}$ & $\begin{array}{r}1986 \\
\%\end{array}$ & $\begin{array}{r}1987 \\
\%\end{array}$ & $\begin{array}{r}1988 \\
\%\end{array}$ & $\begin{array}{r}1989 \\
\%\end{array}$ & $\begin{array}{r}1990 \\
\%\end{array}$ \\
\hline The Netherlands & 5 & -- & 5 & -- & 6 & 7 & 7 & -- \\
\hline (West) Germany & -- & 6 & 7 & 9 & 8 & 9 & 8 & 9 \\
\hline United Kingdom & 7 & 7 & 7 & 7 & 8 & 9 & 10 & 10 \\
\hline Italy & 1 & 1 & 1 & 1 & 2 & 2 & 2 & 2 \\
\hline Belgium & 2 & 2 & 2 & 2 & 2 & 1 & 2 & 2 \\
\hline Luxemburg & 3 & 3 & 3 & 3 & 3 & 3 & 2 & 2 \\
\hline Ireland & 3 & 3 & 3 & 3 & 3 & -- & 3 & 4 \\
\hline Denmark & 10 & 13 & 15 & 16 & 16 & 14 & 10 & 11 \\
\hline Greece & 1 & 1 & 1 & 1 & 1 & 1 & 1 & 1 \\
\hline
\end{tabular}

Source: Eurostat/ROA

Legend: $--=$ not available

Table 7 shows that participation in schooling in the wide sense is highest in Denmark and the United Kingdom, followed by West Germany and the Netherlands. It is extremely low in the other countries, especially Greece. In most countries, the level of participation was more or less constant in the 1983-1990 period; in the Netherlands and the United Kingdom a rising tendency can be perceived over these years.

Table 8 represents participation in schooling in the narrow sense, only 'on-the-job training' being considered. The pattern of this indicator largely coincides with that of the wide indicator, although participation in the narrow sense amounts to only one to three percent. For this indicator Denmark and the United Kingdom again come first, followed now by Ireland and the Netherlands. In the United Kingdom and Ireland this indicator shows a rising tendency over the years. A striking feature is the relatively low participation in schooling in West Germany la country known specifically for its well-developed initial dual education). 
Table 8. Participation in schooling (in the narrow sense) as a percentage of the potential labour force between the ages of 15 and $49 ; 1983-90$

\begin{tabular}{lrrrrrrrr}
\hline & $\begin{array}{r}1983 \\
\%\end{array}$ & $\begin{array}{r}1984 \\
\%\end{array}$ & $\begin{array}{r}1985 \\
\%\end{array}$ & $\begin{array}{r}1986 \\
\%\end{array}$ & $\begin{array}{r}1987 \\
\%\end{array}$ & $\begin{array}{r}1988 \\
\%\end{array}$ & $\begin{array}{r}1989 \\
\%\end{array}$ & $\begin{array}{r}1990 \\
\%\end{array}$ \\
\hline The Netherlands & 2 & - & 2 & -- & 2 & 2 & 2 & - \\
(West) Germany & 0 & 0 & 1 & 1 & 1 & 1 & 1 & 1 \\
United Kingdom & 1 & 2 & 2 & 2 & 2 & 3 & 3 & 3 \\
Italy & 0 & 0 & 0 & 0 & 0 & 0 & 0 & 0 \\
Belgium & 1 & 1 & 1 & 1 & 1 & 0 & 1 & 0 \\
Luxemburg & 1 & 0 & 0 & 1 & 1 & 1 & 1 & 1 \\
Ireland & 2 & 2 & 2 & 2 & 2 & - & 2 & 3 \\
Denmark & 2 & 2 & 3 & 4 & 4 & 4 & 3 & 3 \\
Greece & 0 & 0 & 0 & 0 & 0 & 0 & 0 & 0 \\
\hline
\end{tabular}

Source: Eurostat/ROA

Legend: -- = not available

\subsubsection{Proportion of apprenticeship labour in the labour volume of industrial sectors}

This subsection presents an indicator which shows the percentage share of employees with either primary (table 9) or secondary (table 10) apprenticeship agreements in the labour volume of industrial sectors in the Netherlands. This indicator is calculated on the basis of:

1. the number of primary and secondary apprentices participating in the apprenticeship system (supplied annually by the training institutions and collected by the CBS);

2. data on the labour volume of industrial sectors (supplied annually by the CPB).

The indicator has been calculated for seven industrial sectors, defined by the CORO. Appendix 1 shows which of the industrial sectors defined by the CPB and which training institutions from the CBS data are linked to the sectors defined by the CORO.

The labour volume for each sector is determined by adding the labour volumes of a number of corresponding CPB industrial sectors. The number of primary and secondary apprenticeships for each sector is determined by aggregating the primary and secondary apprenticeships of various training institutions. In calculating the apprentices' share in the labour volume, an apprenticeship is considered as a job in which one works for $80 \%$ of a five-day working week (since apprentices in general spend one day per week in school). Therefore the number of apprenticeships has been multiplied by a labour hour factor of 0.8 .

Table 9 shows that the share of primary apprenticeships is clearly highest in the metals and electrical sectors, followed by the foodstuffs sector. All sectors show an increase of the number of primary apprenticeships in the eighties. This increase is smallest in the printing sector and largest in the foodstuffs sector and the metals and electrical sectors. From 1989 on, the transport sector shows a remarkable increase of primary apprenticeships. 
$-13-$

Table 9. Percentage of labour volume contributed by employees with primary apprenticeship agreements, by industrial sector; $1975,1980,1985-90$

\begin{tabular}{|c|c|c|c|c|c|c|c|c|}
\hline Sector & 1975 & 1980 & 1985 & 1986 & 1987 & 1988 & 1989 & 1990 \\
\hline Metals and electrical & 3.7 & 5.1 & 5.0 & 6.2 & 7.0 & 7.0 & 6.9 & 6.6 \\
\hline Building and wood & 0.9 & 1.9 & 1.9 & 2.2 & 2.3 & 2.4 & 2.5 & 2.8 \\
\hline Foodstuffs & 1.9 & 2.9 & 3.4 & 3.7 & 4.0 & 4.4 & 4.2 & 4.1 \\
\hline Process technologies & 0.5 & 0.9 & 1.4 & 2.2 & 2.0 & 1.8 & 1.9 & 2.0 \\
\hline Printing & 0.7 & 1.6 & 1.2 & 1.5 & 1.8 & 1.8 & 2.0 & 2.0 \\
\hline Transport & 0.2 & 0.3 & 0.5 & 0.6 & 0.6 & 0.7 & 3.7 & 4.0 \\
\hline Textiles and clothing & 0.7 & 0.9 & 1.8 & 2.2 & 2.1 & 2.2 & 1.9 & 2.0 \\
\hline
\end{tabular}

Source: CBS/CPB/ROA

Table 10 gives the share of secondary apprenticeships in each industrial sector. The general picture here broadly corresponds with that of the primary apprenticeships.

Table 10. Percentage of labour volume contributed by employees with secondary apprenticeship agreements, by industrial sector; 1975, 1980, 1985-90

\begin{tabular}{|c|c|c|c|c|c|c|c|c|}
\hline Sector & 1975 & 1980 & 1985 & 1986 & 1987 & 1988 & 1989 & 1990 \\
\hline Metals and electrical & 0.6 & 1.3 & 1.4 & 1.8 & 2.2 & 2.6 & 3.2 & 3.6 \\
\hline Building and wood & 0.4 & 0.4 & 0.6 & 0.7 & 0.8 & 0.9 & 1.0 & 1.1 \\
\hline Foodstuffs & 0.6 & 1.4 & 1.3 & 1.6 & 1.8 & 2.0 & 2.2 & 2.4 \\
\hline Process technologies & 0.0 & 0.1 & 0.0 & 0.1 & 0.6 & 1.1 & 1.3 & 1.6 \\
\hline Printing & 0.2 & 0.3 & 0.2 & 0.3 & 0.6 & 0.6 & 0.7 & 0.7 \\
\hline Transport & 0.0 & 0.0 & 0.0 & 0.0 & 0.0 & 0.0 & 0.4 & 0.3 \\
\hline Textiles and clothing & 0.0 & 0.0 & 0.2 & 0.1 & 0.1 & 0.2 & 0.2 & 0.2 \\
\hline
\end{tabular}

Source: CBS/CPB/ROA 


\section{INCIDENTAL SURVEYS}

\subsection{R\&D workers}

The technological position of a country is determined to a great extent by the production of knowledge and the ability of companies to apply knowledge. Minne (1992) has compared the position of the Netherlands in producing and applying new technology with that of ten other industrialized countries. Although he found that Dutch companies perform reasonably well, looking at the level of investment in Research and Development (R\&D), he pointed to the problem of the relatively high personnel costs of Dutch R\&D workers, which are not matched by demonstrably better quality.

Table 11. Costs and quality of R\&D-workers in companies; 1987,1989

\begin{tabular}{|c|c|c|c|c|}
\hline & \multicolumn{2}{|c|}{$\begin{array}{l}\text { Costs per R\&D worker } \\
\qquad(* 1000 \$)\end{array}$} & \multicolumn{2}{|c|}{$\begin{array}{l}\text { Share of 'researchers' } \\
\text { in R\&D personnel (\%) }\end{array}$} \\
\hline & 1987 & 1989 & 1987 & 1989 \\
\hline Netherlands & 84 & 84 & 34 & 32 \\
\hline France & 75 & 87 & 34 & 36 \\
\hline (West) Germany & 65 & 74 & 36 & 38 \\
\hline United Kingdom & 61 & 72 & 47 & 48 \\
\hline Belgium & 71 & 80 & 38 & 40 \\
\hline Sweden & 70 & 75 & 35 & 35 \\
\hline Norway & 63 & 65 & 57 & 60 \\
\hline Finland & 50 & 60 & 34 & 35 \\
\hline Switzerland & 71 & 73 & 25 & 24 \\
\hline Japan & 64 & 78 & 58 & 59 \\
\hline
\end{tabular}

Source: Minne (1992)

Table 11 shows that the labour costs of Dutch R\&D workers in companies are by far the highest of the OECD countries. Unfortunately, these high costs are not accounted for by the high quality of R\&D workers, at least if the percentage share of 'researchers' (often university educated) is used as an indicator for quality. As can be seen from table 12, the percentage share of researchers among Dutch R\&D workers is not only relatively low but also declining.

\subsection{Vacancies}

Table 12 shows the vacancy level (number of vacancies as compared with employment) in some OECD countries. Since the vacancy level is very cyclically sensitive, standardized unemployment figures are also included for comparison. Finally the time taken to fill a vacancy reported to the District Labour Exchange Bureau is given in the third column. 
Table 12. Vacancy level, unemployment and vacancy duration; 1990

\begin{tabular}{lccc}
\hline & $\begin{array}{c}\text { Vacancy } \\
\text { level }\end{array}$ & $\begin{array}{c}\text { Unemployment } \\
\text { percentage }\end{array}$ & $\begin{array}{c}\text { vacancy duration } \\
\text { in months }\end{array}$ \\
\hline Netherlands & 2.0 & 7.5 & 1.7 \\
France & 1.8 & 9.0 & 1.5 \\
(West) Germany & 3.2 & 5.1 & 1.2 \\
United Kingdom & 1.9 & 6.9 & 0.8 \\
Belgium & 2.2 & 7.9 & 0.9 \\
Sweden & 1.0 & 1.5 & 0.7 \\
Japan & 1.5 & 2.1 & 2.9 \\
\hline
\end{tabular}

Source: OECD, Employment Outlook, 1991, 1992, in: Boot, Thoolen, Meyboom (1992)

From table 12 it can be seen that the Netherlands, like France, have not only high vacancy levels in combination with relative high unemployment figures, but also experience long vacancy durations. This points to the problem of hard to fill vacancies. This problem is also revealed by the business surveys of Eurostat. In these surveys industrial companies are asked whether a shortage of employees is a factor limiting production (table 13, left column) and whether a shortage of educated employees is an important reason for not employing more personnel (table 13, right columns). Table 13 indicates that a shortage of personnel is not a general problem. The shortage of educated labour on the other hand poses a problem, especially in Portugal, Germany, the Netherlands and Italy. Note that percentages for 1989 are higher than the 1985/86 percentages. This can be explained by cyclical sensitivity: 1985/86 was characterized by higher unemployment and weak economic growth, 1989 by a booming economy.

Table 13. Reasons for hard to fill vacancies, according to industrial companies; 1985/86, 1989, 1991 (\% of companies agreeing)

\begin{tabular}{llll}
\hline & $\begin{array}{l}\text { "Shortage of personnel } \\
\text { is a production- } \\
\text { obstructing factor" }\end{array}$ & $\begin{array}{l}\text { "Shortage of educated } \\
\text { personnel is an } \\
\text { important reason for not } \\
\text { hiring more personnel" }\end{array}$ & 1989 \\
\hline Netherlands & 1991 & $1985 / 86$ & 70 \\
France & 3 & 44 & 53 \\
(West) Germany & 6 & 36 & 66 \\
United Kingdom & 4 & 53 & 62 \\
Italy & 5 & 37 & 63 \\
Belgium & 1 & 52 & 28 \\
Ireland & 6 & 20 & 50 \\
Greece & 4 & 35 & 67 \\
Portugal & 1 & -- & 37 \\
Spain & 11 & -- & 62 \\
Total & 3 & 43 & \\
\hline
\end{tabular}

Source: OECD, Employment Outlook, 1992, in: Boot, Thoolen, Meyboom (1992)

Legend: -- = not available 
Boot, Thoolen and Meyboom (1992), and Meyboom (1992), conclude that the Netherlands, compared with other OECD countries, have a high rate of hard to fill vacancies which is indicated by the large number of vacancies as compared with employment, the amount of time it takes to fill vacancies, and the problems companies experience in recruiting educated personnel.

\subsection{Migration}

International migration has consequences for the size and structure of the (active) population of both the emigration and the immigration countries. This section focuses on the consequences of international migration in the late 1980s for the population size (table 14) and the 'ethnic' structure of the labour force (table 15) in some OECD countries.

In the 1980s, virtually all OECD countries, apart from Japan and, in 1989, the United Kingdom, became countries of net migration, that is to say, migration added to the total population size (table 14). In recent years, West Germany has experienced by far the highest rate of net migration. Net migration is also relatively high in Sweden. In the Netherlands net migration, having increased in the 1983/88 period, decreased in 1989. The OECD concludes that migration cannot prevent a long-term decline in the population of OECD countries, nor even its progressive ageing, since 'both would require the admission of new migrants at a very much higher rate than seen over recent decades' (OECD, 1991, pp 30).

Table 14. Average rates of net migration (entries minus exits) per thousand population; 1983-87, 1988, 1989

\begin{tabular}{lccc}
\hline & $1983-87$ & 1988 & 1989 \\
\hline Netherlands & 1.6 & 2.7 & 2.1 \\
France & -- & 0.4 & 0.6 \\
(West) Germany & 0.8 & 5.7 & 11.8 \\
United Kingdom & 0.6 & 0.3 & -0.1 \\
Italy & 1.6 & 1.3 & 0.9 \\
Belgium & 0.0 & 2.2 & 2.2 \\
Sweden & 1.4 & 3.0 & 4.4 \\
United States & 2.7 & 2.7 & 2.6 \\
Japan & -0.1 & -0.2 & -0.1 \\
\hline
\end{tabular}

Source: OECD, Labour Force Statistics, 1969-1989, in: OECD (1991)

Legend: -- = not available

In most OECD countries (except West Germany and Sweden) the pattern of net migration in the 1980s, given in table 14, is reflected in changes in the percentage share of immigrants in the total labour force (table 15). For instance, the recent decline in net migration in the Netherlands has recently been accompanied by a decline in foreigners' share in the total labour force. In West Germany and Sweden however the share of foreigners in the total labour force slightly decreased despite a rather substantial increase in net migration. 
Table 15. Trend in the percentage share of foreigners or immigrants in the total labour force; 1980,1989

\begin{tabular}{lll}
\hline & & $\begin{array}{l}\text { Share of foreigners in } \\
\text { the total labour force } \\
\text { (percentage) }\end{array}$ \\
& 1980 & 1989 \\
\hline Netherlands & & 2.9 \\
France & 3.5 & 6.5 \\
(West) Germany & 6.2 & 6.6 \\
Belgium & 7.8 & 9.8 \\
Sweden & 8 & 5.2 \\
United States & 5.4 & -- \\
\hline
\end{tabular}

Source: OECD, Labour Force Statistics, 1969-1989, and SOPEMI 1989, in: OECD (1991)

Legend: -- = not available

\subsection{Self-employment}

Most countries spend public money on programmes to support persons, particularly unemployed persons, who want to start an enterprise of their own. This section focuses on the share of the self-employed in the total labour force and in employment in major economic sectors (table 16), and on the self-employment intensity in selected branches of economic activity (table 17).

Table 16. Percentage share of self-employment in the total labour force and in employment by major sectors; 1986 or 1987

\begin{tabular}{|c|c|c|c|c|}
\hline \multicolumn{5}{|c|}{ Self-employed as \% of: } \\
\hline & $\begin{array}{l}\text { Total } \\
\text { labour force }\end{array}$ & Agric. & $\begin{array}{l}\text { Employment in: } \\
\text { Ind. }\end{array}$ & Serv. \\
\hline Netherlands & 9 & 50 & 4 & 10 \\
\hline France & 14 & 82 & 9 & 11 \\
\hline (West) Germany & 9 & 36 & 5 & 9 \\
\hline United Kingdom & 11 & 46 & 11 & 11 \\
\hline Belgium & 12 & 69 & 9 & 14 \\
\hline Sweden & 6 & 54 & 3 & 5 \\
\hline
\end{tabular}

Source: ILO statistical database LABORSTA, and World Bank per capita income figures, in: Loutfi (1991)

Table 16 shows that France has the highest share of self-employment in the total labour force and Sweden the lowest, with the Netherlands somewhere in between. In all countries the share of self-employment is by far highest in the agricultural sector. When only the agricultural sector is taken into consideration, France has the highest rate of self-employment. With respect to industrial employment the rate of self-employment is highest in the United Kingdom, while 
Belgium has the highest rate of self-employment when it comes to the service sector.

Table 17 shows the self-employment intensity of selected branches of non-agricultural activity. From table 17 it becomes clear that, when only non-agricultural sectors are considered, selfemployment intensity is highest in Belgium and lowest in Sweden, with the Netherlands once again somewhere in between. In general the rate of self-employment is higher in commerce, construction and finance than in manufacturing, transportation and social, community and personal services. Construction is the most self-employment intensive sector in the United Kingdom and Sweden, while in the Netherlands, Belgium, France and West Germany the highest rate of self-employment is to be found in commerce.

Table 17. Percentage share of self-employment in selected branches of economic activity; 1985,1986 or 1987

\begin{tabular}{|c|c|c|c|c|c|c|c|}
\hline \multicolumn{8}{|c|}{ Self-employed as $\%$ of: } \\
\hline & NAGR & MANUF & CONS & COMM & TRAN & FIN & SOC \\
\hline Netherlands & 7 & 2 & 7 & 16 & 3 & 9 & 4 \\
\hline France & 11 & 5 & 21 & 24 & 5 & 9 & 7 \\
\hline (West) Germany & 8 & 4 & 9 & 18 & 5 & 14 & 5 \\
\hline United Kingdom & 11 & 5 & 35 & 16 & 10 & 12 & 7 \\
\hline Belgium & 13 & 6 & 22 & 30 & 5 & 16 & 6 \\
\hline Sweden & 4 & 2 & 10 & 9 & 7 & 5 & 3 \\
\hline
\end{tabular}

Source: ILO statistical database LABORSTA, in: Loutfi (1991)

NAGR = non-agricultural sector. MANUF = manufacturing. CONS = construction. $\operatorname{COMM}=$ trade, restaurants and hotels. TRAN = transport, storage, communication. FIN = financing, insurance, real estate, business services. SOC = social, community and personal services.

\subsection{Expenditure on labour market programmes}

Table 18 shows public spending on labour market programmes as percentages of GDP in 1990. The programmes have been classified by the OECD into the following seven categories: public employment services, labour market training, youth measures, subsidised employment, measures for the disabled, unemployment compensation, and early retirement for labour market reasons. The first five categories can be considered as 'active' policy measures, while the last two consist of income maintenance for persons out of work.

Table 18 clearly shows that total public expenditure on labour market programmes is highest in Ireland, followed by the Netherlands. The second place of the Netherlands can partly be attributed to income maintenance for persons out of work. When only active measures are taken into consideration, the Netherlands take the third place. A striking feature is the low score of Switzerland and the two non-European countries Japan and the United States, both in active measures and in income maintenance. 
Table 18. Public expenditure on labour market programmes as percentages of GDP; 1990

\begin{tabular}{llll} 
& Total & $\begin{array}{l}\text { Active } \\
\text { measures }\end{array}$ & $\begin{array}{l}\text { Income } \\
\text { maintenance }\end{array}$ \\
\hline Netherlands & & & 2.30 \\
France & 3.34 & 1.04 & 1.92 \\
(West) Germany & 2.65 & 0.73 & 1.16 \\
United Kingdom & 2.18 & 1.02 & 0.90 \\
Ireland & 1.49 & 0.59 & 2.84 \\
Sweden & 4.31 & 1.47 & 0.67 \\
Switzerland & 2.25 & 1.58 & 0.14 \\
United States & 0.30 & 0.17 & 0.60 \\
Japan & 0.85 & 0.25 & 0.32 \\
\hline
\end{tabular}

Source: OECD $(1991) / R O A$

Public expenditure on labour market programmes is partly directed at labour market training. Table 19 indicates public spending on labour market training as percentages of GDP in 1985 and 1990. For 1990, public expenditure on training is categorized under two headings: training for unemployed adults and those at risk of becoming unemployed, and training for employed adults.

Table 19. Public expenditure on labour market training as percentage of GDP; 1985,1990

\begin{tabular}{lcccc}
\hline & 1985 & & 1990 & \\
& Total & Total & $\begin{array}{c}\text { Unemployed adults } \\
\text { and those at risk }\end{array}$ & Employed adults \\
& & & &.. \\
Netherlands & 0.19 & 0.19 & 0.18 & $0.04^{*}$ \\
France & 0.25 & $0.32^{*}$ & $0.27^{*}$ & 0.03 \\
(West) Germany & 0.20 & 0.38 & 0.35 & 0.03 \\
United Kingdom & 0.09 & 0.22 & 0.19 & 0.16 \\
Ireland & 0.66 & 0.49 & 0.33 & 0.01 \\
Sweden & 0.50 & 0.47 & 0.45 &.. \\
Switzerland & 0.01 & 0.01 & 0.01 & 0.03 \\
United States & 0.12 & 0.09 & 0.09 &.. \\
Japan & - & 0.03 & & 0.03 \\
\hline
\end{tabular}

Source: OECD (1991)/ROA

Legend: " 1989 figures

.. $=$ nil or $<0.005$

-- = not available

Although the Netherlands' total public expenditure on labour market programmes is very high, especially with respect to income maintenance, its public expenditure on training is rather modest. Only Switzerland, Japan and the United States score lower than the Netherlands (table 19). In France, the United Kingdom and especially Germany public expenditure on training 
$-20-$

increased significantly during the second half of the eighties, while remaining the same in the Netherlands. As a result the Netherlands' public expenditure on training has become rather low in comparison with most European countries. 


\section{RESPONSE FROM THE NETWORK AND INTEGRATION OF DATA COL- LECTION}

\subsection{Mailing and response from the network of associated institutes}

As in previous years, the most recent report on technology indicators was mailed, in an English version, to the network of sixty statistical bureaus, research institutes, research sections of government departments and individual researchers in France, the United States, Great Britain, Germany and Sweden. It was accompanied by a request for reports or comparative data on education, training and employment that could be significant for a new up-date of our report on technology indicators.

We received fewer reactions to the mailing than last year. Like last year, the usefulness of the information received from the network for inclusion in METING was disappointing. None of it contained really useful internationally comparable statistics on the METING items. However, the response (see Appendix II for an overview of the information received) shows even more clearly than last year the institutes which belong to the 'inner circle' in the field of comparative statistics for the domain that METING covers.

As indicated in last year's report there appears to be little enthusiasm for international cooperation in the existing data collection, since it would entail adapting data files to international standards. This is also the reason why international organizations such as Eurostat, the OECD and UNESCO still provide little detailed, internationally comparable data. However, there are several initiatives in Europe to make national data internationally comparable. An overview of these initiatives, described in last year's report, has been updated and is now presented in section 4.2 .

\subsection{Integration of data collection in Europe}

\subsubsection{Initiatives included in last year's report}

CEDEFOP in Berlin, an official organ of the European Commission, contributes to the development of vocational training types in Europe through research and consultation. In 1990 a socalled 'Flash' appeared in which the results of a number of countries' studies were compared, creating a reasonably comparable review of the costs of, and the participation in, company training. Regrettably there has thus far been no sequel to this first Flash, although this will be worked on.

SYSDEM, the European System of Documentation on Employment, was established in 1990 by the English bureau Ecotec on the authority of the European Commission (DG-V). By means of a quarterly magazine, it provides information on the development of aspects of employment in the EC member states. The information is obtained from national correspondents. However, 
comparisons of the information supplied are thus far impossible.

The Mutual Information System on Employment Policies (MISEP) has the same structure as SYSDEM. Information on the employment policies of EC member states is given through the quarterly magazine InforMISEP.

In 1992 the IEA started the 'Third International Mathematics Study', a project which will take several years. The results of the second research project were described in Van Dam and De Grip (1990). The Dutch research is coordinated through the Faculty of Applied Pedagogy of the University of Twente. In 1994 the 'International Foreign Languages Project' will start. The coordination of the entire project will probably be in the hands of the University of Amsterdam.

Within Eurostat, Department E-1: Statistiques d'Emploi et Chomage, Education et Formation, is charged with the development of studies and corresponding protocols, classifications etc. in the field of the labour market, training and the labour force. The execution of these studies is in the hands of the national Bureaus for Statistics of the member states. As yet, only the 'Labour Force Survey' is conducted annually (as of 1992 with the addition of some new variables). The development of common training statistics is still stalemated by the need for a manageable training classification.

Eurostat has also made a start with the development of forecasts of the population, the labour force and the labour market. An inventory was first made of the institutions in the member states which draw up the corresponding national and regional forecasts. In the first phase Eurostat is focusing on the harmonization and formulation of population forecasts on a national level for the $12 \mathrm{EC}$ member states. In the coming year these forecasts will be regionalised and expanded with forecasts for the EFTA countries. Labour supply forecasts will be formulated in the second phase. The forecasts are expected to be formulated on a biannual basis with a forecasting period of thirty years and will appear in three versions.

\subsubsection{Recent initiatives}

The Task Force for Human Resources, Education, Training and Youth of the European Commission (Task Force) has commissioned a project for the construction of a 'Management Chart on Continuing Vocational Training' (CVT) in companies in the EC. The project has three stages. In the first stage an inventory of existing data on CVT was made by Germany, France and the United Kingdom. Special attention was paid to comparing definitions and constructing a general short-list of common items which should be gathered by other EC member states. In the second stage, institutes in the Netherlands, Luxemburg, Ireland, Denmark and Spain made an inventory of existing data on CVT for their country and compared them with the general short-list of items and variables on CVT. In the Netherlands this project was carried out by ROA and the Centre for Applied Research in Education (Brandsma, Van Dam, De Grip, 1992). In the third stage of the project institutes of the remaining EC countries will describe the availability and content of data on CVT in their countries. 
CEDEFOP has founded an international project team for the definition of indicators for the relationship between training and employment. The team's first proposals contain 14 indicators, which can be divided into two groups:

1. Key indicators, based on information which is usually available and can easily be compared between countries:

- general rate of unemployment among young people;

- coefficient showing the impact of vocational training on unemployment among young people;

- relationship between the rate of unemployment and the average period of unemployment for young people with initial training;

- rate of non-permanent employment;

- rate of under-utilization of skills deriving from initial or continuing training;

- rate of change in qualifications after training is undertaken, according to type of training;

- coefficient for the period of unemployment (with initial training/ without initial training).

2. Supplementary indicators of significant importance, some of them requiring information that is not yet available:

- job turnover rate for young people with initial training or after further training;

- employability rate after completion of initial training;

- rate of new job procurement by workers with further training;

- average time lapse between the end of initial training and entry to the labour market;

- rate of discouragement among youngsters;

- mobility coefficient.

At the moment, discussions are going on between CEDEFOP, EUROSTAT and European research institutes (i.e. ROA) on the desirability, practicability and possibilities for the realisation of these indicators. As some of our corresponding institutes reported, the OECD has started with the INES-project (International Indicators and Evaluation of Educational Systems), which is meant to provide data on the relation between higher education and the labour market. At the moment, no further information is available, but this will be given in the coming report. 


\section{CONCLUSIONS}

\section{Key indicators}

One of the seven key indicators on the position of the Netherlands with regard to the implementation of technology, the indicator of the labour-market situation for the technically skilled, could not be updated this year. The findings, with respect to the Netherlands, from this year's update of the key indicators can be summarized as follows:

1. a continuing decrease of the 15-24 year age bracket's participation in dual-system education and in vocational education, starting in 1988, and thus a weakening of the breeding ground for the diffusion of technological advance;

2. a declining tendency in the share of technically educated school-leavers in the classes of the 1990s, reducing the share of the technically educated in the potential labour force, and thus eroding the Netherlands' scientific and technological breeding ground in terms of innovation as well as diffusion;

3. a tightening labour market situation for technically educated school-leavers, indicating a growing need for training to overcome present or possible future impediments to the further diffusion of technological progress;

4. the 15-24 year age bracket has over recent years declined as a proportion of the total population, indicating a decreasing ability to respond to the changed educational requirements due to technological progress (since adjusting initial education will have less effect as the proportion of young people in the labour force is lower);

5. a relative young active population and a low and declining proportion of people between the ages of 50 and 65 in the active population, indicating a low 'vulnerability' of the existing labour force to technological progress and a low need for retraining;

6. a high and growing participation in schooling by the 15-49 year age bracket (for apprenticeships particularly in the foodstuffs and the metals and electrical sectors), indicating a growing scientific and technological breeding ground for, in particular, the diffusion of technological advance.

The two last conclusions, relating to participation in (post) initial education by the 15-49 year age bracket, point to the existing healthy breeding ground for the diffusion of technological advance. However, the first four conclusions mentioned above indicate the vulnerable position of the Netherlands with respect to participation in (initial) education by the 15-24 year age bracket, thus eroding the breeding ground for the future diffusion of technological advance.

\section{Incidental surveys}

Although the Netherlands' total public expenditure on labour market programmes is very high, especially with respect to income maintenance, its public expenditure on training has become rather low in comparison with most European countries.

In the light of the conclusions mentioned above, it is not hard to understand why the Nether- 
lands, compared with other OECD countries, experience a high rate of hard to fill vacancies. This is indicated by the large number of vacancies as compared with employment volume, the amount of time it takes to fill vacancies, and the problems Dutch companies experience in recruiting trained personnel.

Although Dutch companies perform reasonably well, looking at the level of investment in R\&D, the relative high personnel costs are not matched by the demonstrably better quality of R\&D workers.

In the Netherlands net migration, having increased in the $1983 / 88$ period, decreased in 1989 . The recent decline in net migration has been accompanied by a decline in foreigners' share in the total labour force.

The Netherlands' position with respect to the share of self-employment in the total labour force lies somewhere in between other OECD countries. As in other countries the rate of selfemployment is by far highest in the agricultural sector. Outside the agricultural sector, the highest rate of self-employment is to be found in commerce.

\section{Network mailing and integration of data collection}

This year's mailing to our peer network (intended for the collection of additional, internationally comparable, data) has, like last years', produced less immediate 'hits' than the first year. However the response (see appendix 1) shows even more clearly than last year the institutes and persons who belong to the 'inner circle' in the field of comparative statistics for the domain that METING covers. Since international cooperation in the collection of data entails adapting data files to international standards, international organizations such as Eurostat, the OECD and UNESCO can still provide little detailed, internationally comparable, data.

Nevertheless, there are initiatives by European institutes (often concentrating on the comparison of one aspect of technology, labour or training) to integrate data collection in order to make national data internationally comparable. Our participation in the METING project should therefore remain focused on the developments of such initiatives and on any relevant international publications. 


\section{ABBREVIATIONS}

CBS : Centraal Bureau voor de Statistiek (Dutch Central Bureau for Statistics)

CEDEFOB : European Centre for the Development of Vocational Training

CPB : Centraal Plan Bureau (Dutch Central Planning Bureau)

CORO : Centraal Orgaan Regionale Organen leerlingwezen (Central Organ of the Regional Organs for the apprenticeship system)

EC : European Community

Eurostat : European Bureau for Statistics of the European Community

IAB : Institut für Arbeitsmarkt- und Berufsforschung

IEA : International association for the evaluation of Educational Achievement

ILO : International Labour Organisation

MERIT : Maastricht Economic Research institute on Innovation and Technology

MOW : Ministerie van Onderwijs en Wetenschappen (Dutch Ministry of Education and Science)

OECD : Organisation for Economic and Cultural Development

ROA : Researchcentrum voor Onderwijs en Arbeidsmarkt (Research Centre for Education and the Labour Market)

UNESCO : United Nations Educational Scientific and Cultural Organisation 


\section{SOURCES}

Boot, P.A., J. Thoolen, P. Meyboom (1992), Vacatures in internationaal perspectief, in: Economisch Statistische Berichten, no. 3871, pp. 748-752.

Brandsma, T.F., J.W. van Dam, A. de Grip (1992), Continuing vocational training in the Netherlands, Managing Chart, Enschede, Maastricht.

Centraal Bureau voor de Statistiek (*), Statistiek van het beroepsonderwijs, Den Haag.

Centraal Bureau voor de Statistiek $\left({ }^{*}\right)$, Volwasseneneducatie, Den Haag.

Centraal Plan Bureau ("), Centraal Economisch Plan, Den Haag.

Dam, J.W. van, A. de Grip (1990), Technology Indicators: Population, Labour and Schooling. 1990 Report, ROA-R-1990/5E, Maastricht.

Dam, J.W. van, B.J.H. Lodder, G.W.M. Ramaekers (1991), Technology Indicators: Population, Labour and Schooling. 1991 Report, ROA-R-1991/9E, Maastricht.

Eurostat (*), Labour Force Survey, Luxemburg.

Grip, A. de (1987), Onderwijs en Arbeidsmarkt: Scholingsdiscrepanties, Amsterdam.

Grip, A. de, W.J. Nusselder (1989), Technology Indicators referring to Education and Labour, ROA-R-1989/4E, Maastricht.

International Labour Organisation (*), Yearbook of Labour Statistics, Geneva.

Loutfi, M.F. (1991), Self-employment patterns and policy issues in Europe, in: International Labour Review, vol. 130, no. 1, pp. 1-19.

Meyboom, P. (1992), Minimumloon, uitkeringsniveau en arbeidsschaarste in de Euregio MaasRijn, ROA-W-1992/6, Maastricht.

Ministerie van Economische Zaken, Directie ATB (1990), METING 2. Indicatoren voor de technologische positiebepaling van Nederland.

Ministerie van Onderwijs en Wetenschappen (1990), Skill-prognoses 1990, Den Haag.

Ministerie van Onderwijs en Wetenschappen (1991), Referentieraming 1991. Deel VIII Tijdreeksen uit de referentieraming 1991, Den Haag. 
$-28-$

Minne, B (1992), De technologische positie van Nederland, in: Economisch Statistische Berichten, no. 3871, pp. 748-752.

Organisation for Economic and Cultural Development (1991), Employment Outlook 1991, Paris.

Organisation for Economic and Cultural Development (*), Labour Force Statistics, Paris.

United Nations Educational Scientific and Cultural Organisation (*), Statistical Yearbook, Paris.

$(*)=$ several annually updated versions used. 
$-29-$

APPENDIX I: CLASSIFICATION OF INDUSTRIAL SECTORS

\begin{tabular}{|c|c|c|}
\hline CPB sector & CORO sector & $\begin{array}{l}\text { Types of training distinguis- } \\
\text { hed by the CBS }\end{array}$ \\
\hline $\begin{array}{l}\text { base metals industries, metal pro- } \\
\text { duction, } \\
\text { electrical industries }\end{array}$ & metals and electrical & $\begin{array}{l}\text { metal technologies I to IV, } \\
\text { automobiles, body work, and } \\
\text { installation techniques }\end{array}$ \\
\hline $\begin{array}{l}\text { Wood and building materials and the } \\
\text { construction industry }\end{array}$ & building and wood & $\begin{array}{l}\text { construction technology, } \\
\text { woodwork, painting, road } \\
\text { construction and furniture } \\
\text { making }\end{array}$ \\
\hline foodstuffs industry & foodstuffs & foodstuffs technology \\
\hline chemical and rubber industries & process technologies & $\begin{array}{l}\text { process, measurement and } \\
\text { control technologies }\end{array}$ \\
\hline paper and printing industry & printing & printer's training \\
\hline transportation industry & transport & $\begin{array}{l}\text { harbour and transport com- } \\
\text { panies, nautical training, } \\
\text { passenger and goods trans- } \\
\text { port }\end{array}$ \\
\hline $\begin{array}{l}\text { textiles, clothing, leather and foot- } \\
\text { wear industries }\end{array}$ & textiles and clothing & $\begin{array}{l}\text { textile \& clothing industry, } \\
\text { jewellery and engraving } \\
\text { techniques }\end{array}$ \\
\hline
\end{tabular}




\section{APPENDIX II: INFORMATION RECEIVED FROM THE NETWORK}

As in previous years, we asked sixty scientists, scientific institutes or international bureaus in France, the United States, Great Britain, Germany and Sweden for reports and comparative data on education, training, work and employment. We received reactions from the following institutes.

The Universities Statistical Record in the United Kingdom sent Volume II of 'University Statistics 1989-90', concerning the first destinations of university graduates.

The US Department of Labor, Bureau of Labor Statistics, in the United States sent:

- projections for the development of employment in the USA in general and the development of scientific and technical employment in the USA for 1990-2005 in particular;

- occupational projections and training data;

- articles and figures on graduates.

The ILO, Training Policies Branch, sent two suggestions for interesting scientific articles. The ILO pointed out the need for comparable figures on a project in the field of retraining needs and new occupational profiles in commerce and office work.

The Commission of the European Communities, Task Force Human Resources, Education, Training and Youth sent:

- a 'Rapid Report on Population and Social Conditions (1992/1)' by Eurostat with figures on education in the $\mathrm{EC}$ during the eighties;

- Eurostat figures on school entrants and pupils and students by educational level, gender and nationality.

Statistics Sweden, the Department of Labour and Educational Statistics, in Sweden:

- sent a letter with useful remarks on our requests;

- promised to send information in the near future;

- gave information on the INES-project of the OECD which, among other things, deals with the relationship between higher education and the labour market.

The IAB in Germany sent:

- information on their work on the Educational Accounting System (Übergänge zwischen Bildung, Ausbildung und Beschäftigung und die Entwicklung der Qualifikationsstruktur);

- 'Bildung und Beschäftigung im Wandel, Die Bildungsgesamtrechnung des IAB';

- an 'IAB-Kurzbericht' and two articles on forecasts of the demand for vocational qualifications in Germany towards 2010.

In their letter the IAB also noted the INES project of the OECD, and a joint project of the OECD and the EC on science and technology personnel. In some of their publications the IAB presents figures for EC countries on youth unemployment and the educational participation of youngsters. 